\title{
SOLAR POWER IN BUILDING DESIGN, THE CASE OF NTC TOWER IN THE SUDAN
}

\author{
Omer A. Abuelzien\#1, Rania A. Osman *2 \\ ${ }^{1}$ Faculty of Engineering, Najran University, Najran 1988, KSA \\ 2 Jubail University College, Fine Art Department,Jubail, KSA \\ 1 oabuelzein@gmail.com \\ 2 osmanr@ucj.edu.sa,
}

\begin{abstract}
Zero energy buildings is one of the methodologies to achieve green Architecture goal which combine energy efficiency and renewable energy generation to consume as much energy as can be produced onsite.

The aim of this study is to describe current approaches to integrate solar photovoltaic power systems in architecture to achieve energy efficiency in buildings taking the National Telecommunications Corporation tower, (NTC Tower), in Sudan as an example of such buildings, which integrates solar cells in its envelope. In this research, we calculate the energy consumption in this tower and analyze the input of the integrated solar cells by presenting a simulation detailed model of the building. This allows us to examine the details of its energy performance. Based on this analysis the paper sets recommendations for enhancing energy efficiency building by integrating solar cells in buildings.
\end{abstract}

Keyword - Energy Consumption1, Solar Power2, Renewable Energy3, photovoltaic systems4

\section{INTRODUCTION}

Driven by the increasing population, developing economy and a quest for improved quality of life, energy consumption has increased and its growth rate is continuing to rise, fueling the energy demand further. Increased energy consumption will lead to more greenhouse gas (GHG) emissions with so many impacts on the environment. The expected increase in energy demand, along with the predominance of coal in the energy mix, highlight the significance of promoting energy efficiency. Higher rate of urbanization with increased floor space for both residential and commercial purposes has imposed enormous pressure on the existing sources of energy. Limited availability of the existing energy resources and transient nature of renewable energy sources have enhanced the significance of energy efficiency and conservation in various sectors. In Sudan, consumption of electricity has increased in the commercial sector in the past ten years. In commercial buildings, the annual energy consumption per square meter of the floor area is in excess of $200 \mathrm{~kW} \mathrm{~h}$ with air-conditioning and lighting serving as the two most energy consuming end-use applications within a building. Growth of energy consumption in building sector is rocketing. This caused primarily by the growth in population, households demands, and commercial floor space, which are expected to increase by $28 \%$ within 2035 . With the improvement of Sudanese economic situation and people's living standards, the energy crisis and environmental degradation are becoming apparent. Building energy consumption accounts for $25 \%$ to $40 \%$ of the total energy consumption, together with transportation and industry as the three major energy consuming households, building energy efficiency plays an important role in the national energy conservation strategies. As the large construction number of buildings energy-saving or not, will no doubt have positive practical significance to realization of building energy conservation and environmental protection. [2] 


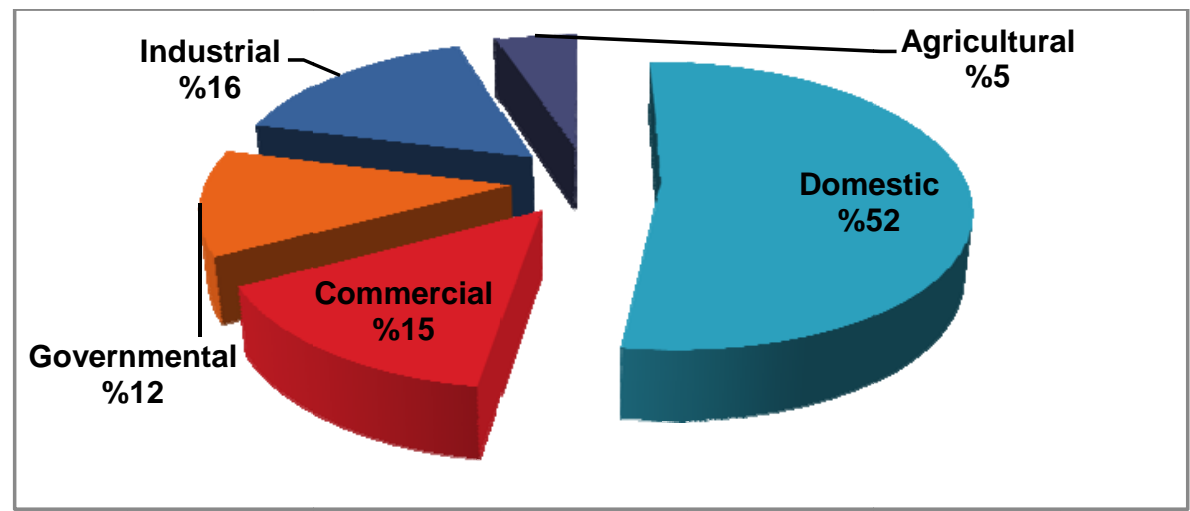

Fig. 1: Energy consumption in each sector in Sudan, Ref. Yasir, 2013

Architects should play a key role in future solar-integrated architecture, as they are responsible for the building process right from the beginning. Solar-integrated architecture takes into consideration both passive and active use of solar energy.[1] The aim of this research was to gain insight view of the actual design processes of solarintegrated buildings.

This paper, discusses the solar energy building integration technology, and its application in an office building. It also explores a new way of thinking for enhancing the energy production in a building by examining the current situation of the solar system integrated in the NTC tower and testing different scenarios to develop the systems and evaluate each option using Energy simulation method. [2]

As buildings, have renewable energy, abundant solar radiation, non-polluting air, more and more people of all ages will remain fit and healthy still. The Sudan is extremely rich in solar radiation. The total annual solar radiation amounts to more than 5.02 million $\mathrm{KJ} / \mathrm{m} 2$. Annual sunshine hours is over $2200 \mathrm{~h}$ areas accounts for more than two-thirds of the land area, so there is great potential in the use of solar energy[1].

Currently, the use of solar energy in our country has made significant achievements, but the degree of understanding of solar energy and building integration technologies is still not satisfactory. The aim of applying solar energy and building integrated technologies is to link, incorporate the use of solar energy into the overall design of the local environment, harmonizing architecture, technologies with aesthetics values in an organic figure, and make solar facilities to be part of the building.

\section{METHODOLOGY:}

One of the aims of this research is to access an optimal energy model for the selected case study (The NTC Tower) in Sudan, and to provide better option for solar energy to run the building systems. To reach the aims stated, the research applies the (Generated and Test Technique), where we make our ideas under test to perform them using the Autodesk Ecotect Analysis software. Initially we construct energy consumption models that simulate a building for energy consumption prediction or energy saving estimates, and simulate the existing situation as it is. Then starting simulating the different techniques of sustainable and environmental architecture. We studied several scenarios to choose the best. Finally, we created an imaginary model of for the existing tower, which has a better energy performance than the first option.

\section{APPLICATION OF SOLAR ENERGY AND BUILDING, INTEGRATION TECHNOLOGY IN} OFFICE BUILDING

The application of solar energy and building integration technology in buildings, mainly has three aspect: solar thermal technology, solar photovoltaic technology, solar optical technology, and mainly set on roofs, balconies, exterior walls and somewhere with ample sunshine.

\subsection{Solar Thermal Technology}

Solar energy is mainly used to supply domestic hot water, heating and refrigeration. In designing the integration of solar hot water system in buildings, the need is not only for considering the layout of solar hot water system, but also to improve the form of the system itself. Traditional solar hot water system with vacuum tube cannot meet the needs of the ever-changing layout and style of the buildings. Beyond that, it has other deficiencies, such as the difficult installation, easy destruction of waterproof layer of the roof, security risks if the lightning protection and draught exclusion devices are not in place, vacuum tube wear quickly, and water pipes that exposed to the outdoor cause large heat loss, etc. In short, the traditional solar hot water system with vacuum tube cannot meet the need of integration of solar energy in buildings either in quality or in performance. Now, the flat plate solar collector system is gradually replacing the solar hot water system with vacuum tube, for, it has higher adaptability, and the its installation can better achieve the perfect combination with the construction [4]. Solar collector system mainly operate on the split double-cycle under pressure. The hot water tank can be located in the basement, attic, staircase room, balcony and/or any other adequate places. In order to achieve a 
large amount of water, water tank can be a single one, double or even a multi-tank. If the tank capacity is increased, the installation area will corresponds to meet the hot water needs. Hot water is not only used in bathrooms, but also used for heating and cleaning kitchen utensils. The water quality should be clean to meet the drinking water standards.

Integrating solar collector with the roofs, balcony rails of the south façade, bay windows and walls, can make the appearance of buildings be overall unified, and have rich hierarchies [5]. When installed on the sloping roof, the solar collector can be embedded in the roof like a sunroof or flat out on the roof, integrating with the construction to increase the building beauty.

When installed on the flat roof, the flat-plate solar collector can act as roof covering or insulation layer, not only conforms to the residential modeling requirements, but also avoids the repeated investment and reduce the cost. In addition, the flat-plate solar collector can be combined with balconies, bay windows, outside walls of buildings, to maximize the use of solar energy and provide new ways and means to the residential façade design, and achieve the aim of multi-purpose as well.

\subsection{Solar Photovoltaic Technology}

Solar photovoltaic technology applying in buildings is mainly used for photovoltaic conversion and lighting. Building Integrated Photovoltaic (BIPV) is a new concept for the application of solar power. In short, it is installing the solar photovoltaic phalanx on the surface of the maintenance structure of the building to provide electricity [6]. Photovoltaic arrays do not take up additional floor space when integrate with the construction. It is the best installation way of photovoltaic generation system, thus attracting much attention.

BIPV can be divided into two categories according to the forms that photovoltaic array integrated with the buildings [7]. One is the combination of photovoltaic array with building, installing the PV array on the building, and the building plays a supportive role as a photovoltaic carrier. The other is the integration of photovoltaic array with building, PV modules appears as a building material, and the photovoltaic array becomes the integral part of the construction. Such as photoelectric tile roof, photoelectric curtain wall and photoelectric lighting roof, etc.

\subsection{Solar Optical Technology}

The main use of the solar optical technology in buildings is for lighting, natural light can enter into the function rooms through the light guide tube, thus improve the indoor daylighting situation, such as underground garage, equipment room and storage room. Because utilization of solar optical system is also subjected to the impact of the climate, this technology is suitable for the regions that have abundant natural light and less cloudy sky [8]. The light guide tube is mainly composed of three parts: a light collector for collecting the daylight; tubing portion for transmitting light, and the light exit portion for controlling the distribution of the light in the room. Using the light guide tube on the roof must ensure that there have no obstructions, and well water treatment to avoid leaking during the installation. Moreover, as the instability of the natural light, the light guild tubes must in combination with the adjustable artificial light, to be an effective supplement when the daylight is insufficient.

\section{CASE STUDY}

The case study shown below depicts the efforts done to create of energy-efficient buildings integrated solar cells with its construction. The short project summary describes key features and lessons learned from the project.

The NTC Tower is a skyscraper in Khartoum, The Sudan. The 29-story building finished in 2009. Its construction began in 2005. [2] The contractor was the Turkish company AINA International.

The total area of the site is 5000 square meters and the built up area of the ground floor is 3000 square meters. The typical floor area is 980 square meters and the total built up area is 32,000 square meters. The total number of floors is 29 floors with a total height of 110 meters plus a telecommunication antenna, which is 30 meters high.
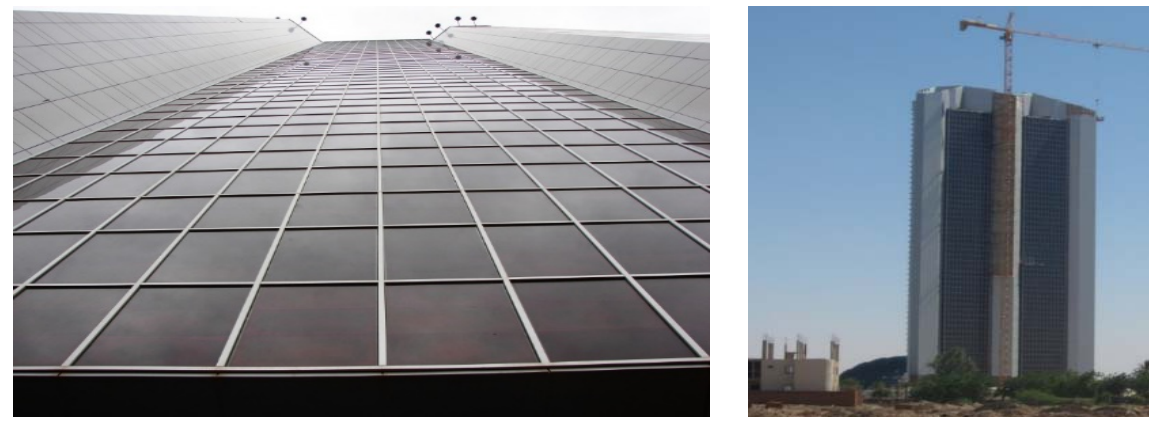

Fig.2: National Telecommunications Corporation Tower NTC in Khartoum, The Sudan 


\subsection{NTC Tower characteristic}

1. The NTC Tower has the following characteristics and advantages:

2. Solar power interfaces provide about $20 \%$ of the required electrical power for the building.

3. The tower has six elevators including four internal elevators and two external Panoramic Lifts as well as escape staircases and main stairs.

4. There is also an escalator for VIP visitors and employees.

5. Integrated Information Service to the automatic response in addition to an integrated scope to control the management of the building in terms of insurance and control.

6. A large conference hall with a capacity of 280 users in addition to small meeting rooms on the administrative floors.

7. A Large Modern cafeteria and an underground car park.

8. Glass facade of the building overlooking the Blue Nile.

9. Three public gardens in front of the building and face the Blue Nile.

10. Data center, laboratories to conduct measurements and type clearance for equipment and systems used and conduct research and studies.

11. Interior finishing materials: The floors were finished with natural stone in addition to the ceramics for the bathrooms; the false ceiling was made of aluminum in some areas and gypsum in other areas.

12. Exterior finishing materials: The exterior of the building has been finished with strips of aluminum cladding, in addition to double glass with natural stone works on the ground floor level. Solar PVC cells in one elevation.

The main Architectural drawings of the building are as follows:

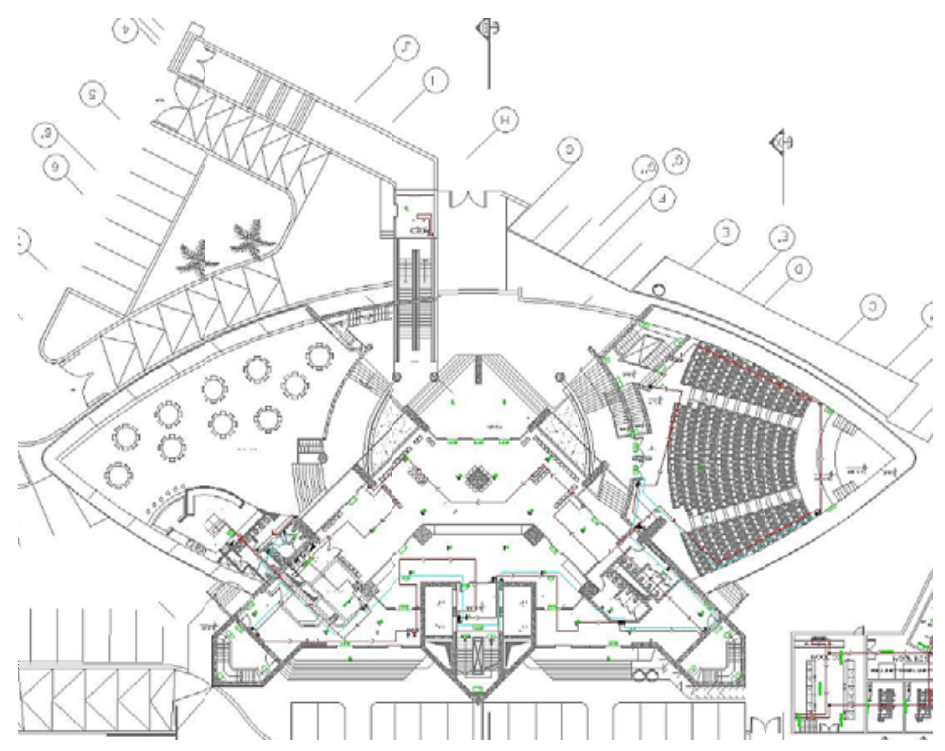

Fig. 3: Ground Floor Plan - on level 3.60m:
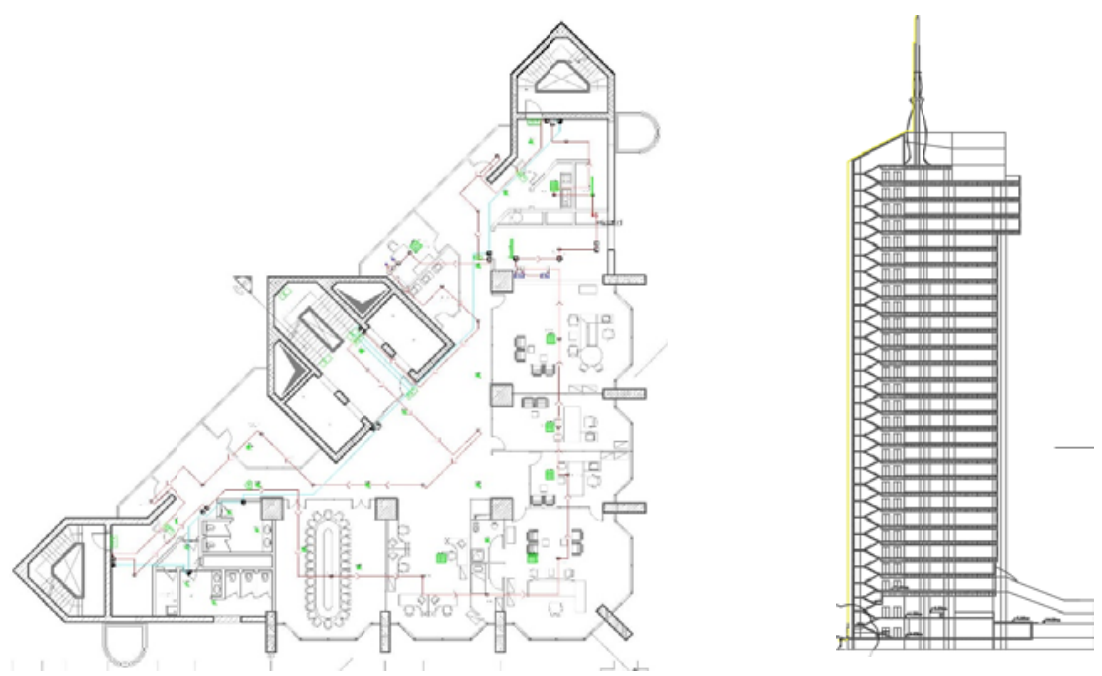

Fig. 4: Typical Floor Plan and Section 


\subsection{NTC Photovoltaic system information}

The Solar System Used is thin film solar cells. The following table shows the cell specifications and sizes.

Table 1:shows cell and plate information (source: researcher)

\begin{tabular}{|c|l|l|}
\hline & Item & Description \\
\hline 1 & Cell type used in system & Silicon cell cells (semi-transparent cells) \\
\hline 2 & Components of Solar Panel & Glass / Solar Panel / Glass \\
\hline 3 & $\begin{array}{l}\text { Sizes of the solar panel Dimensions of the } \\
\text { panels according to the design }\end{array}$ & $\begin{array}{l}\text { (different according to the location in the façade, } \\
\text { most of which are 1.25 m width) }\end{array}$ \\
\hline 4 & Plate thickness & $\begin{array}{l}\text { (glass } 5 \mathrm{~mm} / \text { solar unit } 2 \mathrm{~mm} / \text { glass } 5 \mathrm{~mm} \text { ) } \\
\text { Total } 12 \mathrm{~mm}\end{array}$ \\
\hline 5 & Electrical capacity in watt & $90 \mathrm{wp} / \mathrm{m} 2$ \\
\hline 6 & Effectiveness rate & $9-12 \%$ \\
\hline
\end{tabular}

Photovoltaic cells are integrated into the southwestern façade of the building to serve as an energy generator, providing $20 \%$ of the electricity needed to operate the building, which is used for lighting. It also acts as a shading and a barrier to vision. SMA for solar technology designed the solar system. It is consists of two main components: solar panels and the prevailing system.

The solar panels are consist of thin solar cells that are multilayered cells, which are made of silicon material used in grayish blue. Figure (5) shows the location of the cells in the tower.

The cells were installed on the façade of the Southwest building as a curtain wall serving a total area of 2430.6 square meters.
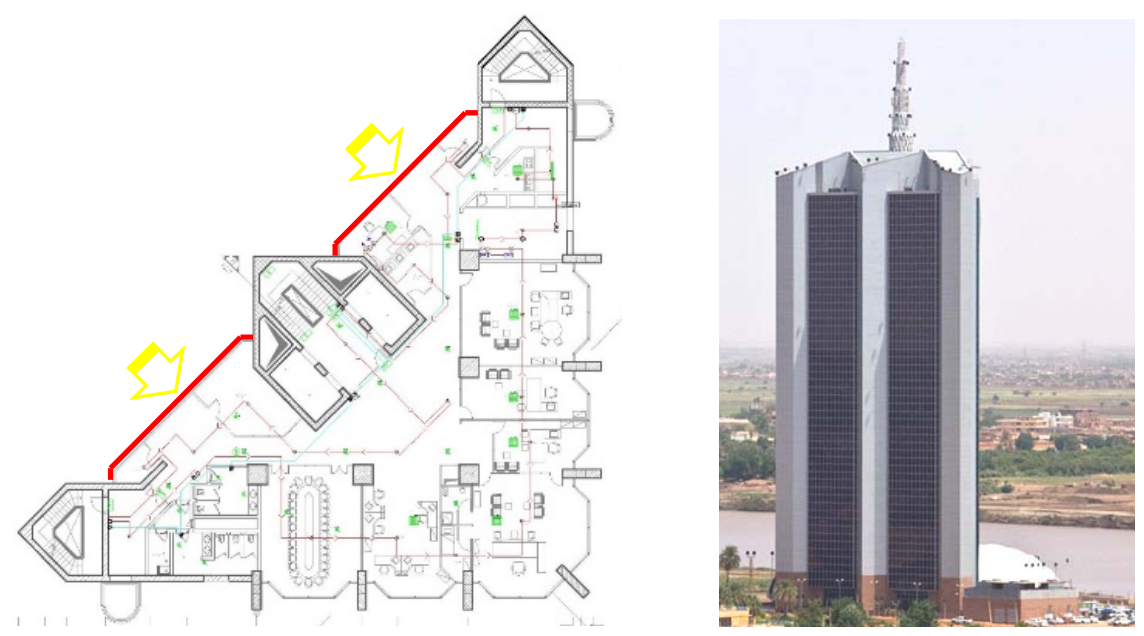

Fig. 5: Southwestern Elevation shows the Solar cells integrated in the Building envelope.

The following table shows the level of solar radiation and the average electricity output of the cells installed in the tower. 
Table 2: ELECTRICITY PRODUCTION FROM THE GIVEN SYSTEM (KWH), (SOURCE: RESEARCHER)

\section{orientation 70 degrees and constant inclination 90 degrees}

\begin{tabular}{|c|c|c|c|c|}
\hline Hm & Hd & Em & Ed & Months \\
\hline 122 & 3.95 & 7900 & 255 & Jan. \\
\hline 116 & 4.14 & 7490 & 267 & Feb. \\
\hline 120 & 3.88 & 7760 & 250 & March \\
\hline 109 & 3.64 & 7020 & 234 & Apr. \\
\hline 101 & 3.25 & 6440 & 108 & May \\
\hline 94 & 3.13 & 6000 & 200 & Jun. \\
\hline 91.4 & 2.95 & 5840 & 188 & Jul. \\
\hline 96.1 & 3.1 & 6160 & 199 & Aug. \\
\hline 104 & 3.47 & 6700 & 223 & Sep. \\
\hline 120 & 3.86 & 7720 & 249 & Octo. \\
\hline 120 & 4.01 & 7770 & 59 & Nov. \\
\hline 121 & 3.91 & 7830 & 252 & Dec. \\
\hline 110 & 3.60 & 7050 & 232 & One year \\
\hline 1310 & 46.89 & 84600 & 2716 & Total \\
\hline
\end{tabular}

Where:

Ed: Average daily electricity production from the given system (kWh)

Em: Average monthly electricity production from the given system (kWh)

Hd: Average daily sum of global irradiation per square meter received by the modules of the given system $\left(\mathrm{kWh} / \mathrm{m}^{2}\right)$

Hm: Average monthly sum of global irradiation per square meter received by the modules of the given system $\left(\mathrm{kWh} / \mathrm{m}^{2}\right)$

The following table shows the economic analysis of the system:

Table 3: The economic analysis of the system

\begin{tabular}{|l|l|l|}
\hline & Item & Description \\
\hline 1 & The system life span & $\begin{array}{l}60 \text { years old and the warranty period is } 25 \\
\text { years }\end{array}$ \\
\hline 2 & The building life span & s 35 years old \\
\hline 3 & The total cost of the system in the pound on 23/8/2005 & $8,154,075.40$ \\
\hline 4 & $\begin{array}{l}\text { The cost of a wall of glass curtain wall/ Sudanese } \\
\text { Pound }\end{array}$ & $5,544,862.58$ \\
\hline 5 & $\begin{array}{l}\text { The price difference between the solar cells and the } \\
\text { glass curtain wall in SDP }\end{array}$ & $2,609,212.82$ \\
\hline 6 & $\begin{array}{l}\text { The cost of energy consumed by the building per } \\
\text { month in SDP }\end{array}$ & $\begin{array}{l}1,094,979.8 \\
\text { in Sudanese pounds 21,899 }\end{array}$ \\
\hline 7 & $\begin{array}{l}\text { The cost of energy provided by solar energy } \\
\text { The cost of energy provided by the system per year in }\end{array}$ & 262788 \\
\hline 9 & $\begin{array}{l}\text { Time to recover the cost of setting up the system in the } \\
\text { year }\end{array}$ & 9.9 \\
\hline
\end{tabular}

4.3 Prepare a model for the building to be analyzed

1. The simulation work begins by building a model that conforms to the specifications of the existing building using Autodesk - Revit 2016 software as shown in Figure (6). The construction is done step by step, taking into account all the openings, internal divisions and materials. This affects the energy calculations at the start of the simulation.

2. The following are the basic steps that have been followed in the Autodesk program to prepare the model for the NTC tower: 
3. Open a new file: An empty file has been created and named (Case Study)

4. Processing the project browser list: which enables the project to browse and find all the required drawings in the project and it was as follows: (25 Floor Plans, one section, four elevations, three-dimensional drawings)

5. Build the model according to the studied material specifications as it is on the site, by adding the floors, walls and openings, and start with the ground floor only as it appears in Figure (6). After the ground floor model is completed with all its details, the floor will be copied because it is typical floor with some slight changes.

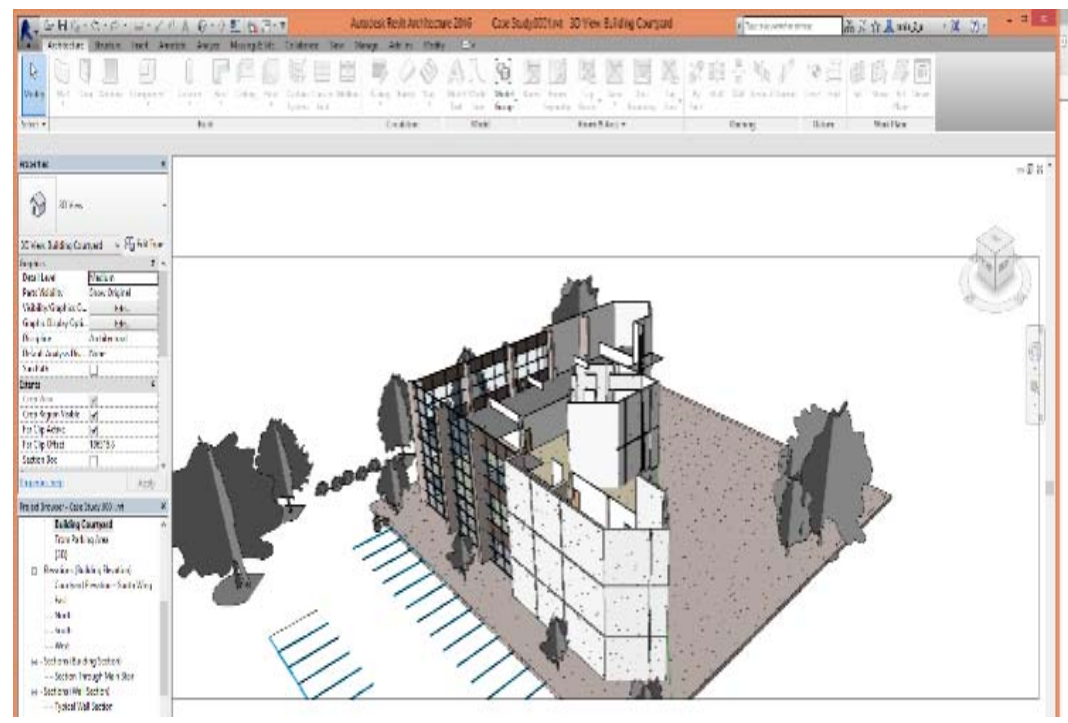

Fig. 6: ground floor model is completed with all its details

Energy setting is adjusted and entered accurately to the program. See Figure. 7.

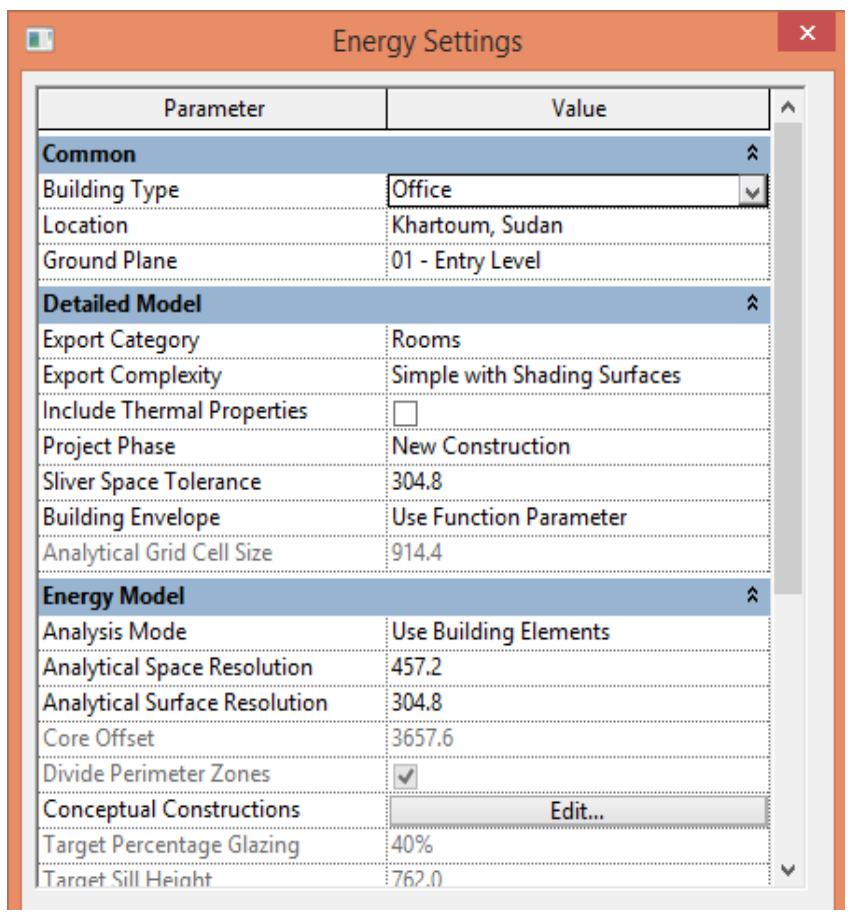

Fig. 7: Details of Energy setting

6. The location set in the previous step will automatically set the sun path to the site and all other climate conditions. See Figure. 8. 


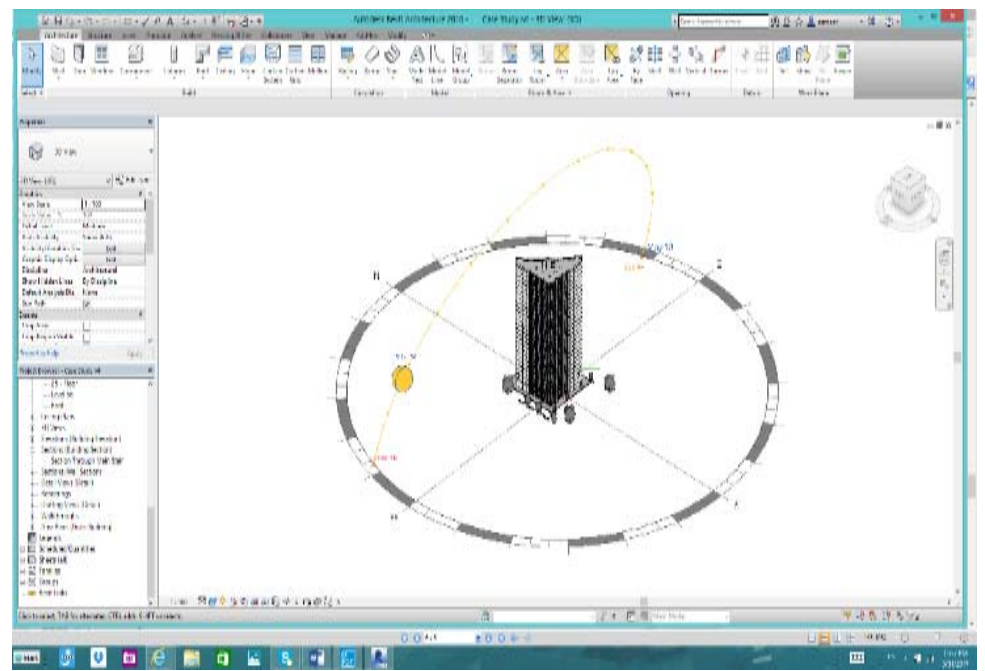

Figure 8: Sun Path and climate setting.

7. Then the simulation process started and a detailed analysis report is given. See Figure 9 and Figure 10. for summary of the report.

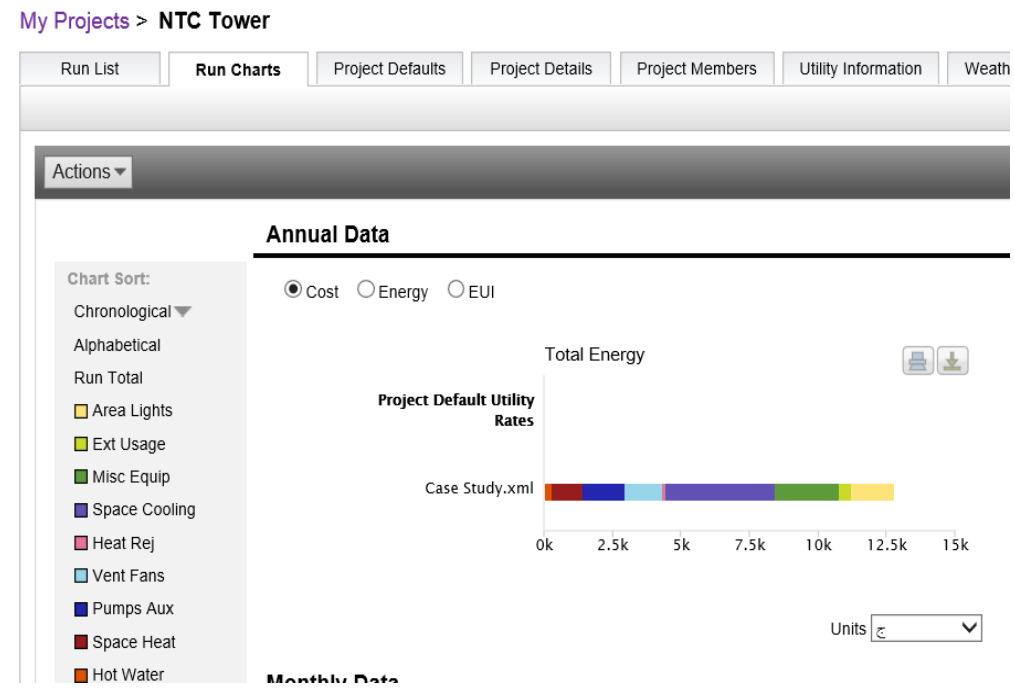

Fig. 9: Summary of the Energy consumption in NTC Tower

8. The simulation report shows that the highest is the cooling cost second came the lighting cost and this is clear in the peak electric demand chart where the highest demand of electricity is within summer session (May to October).
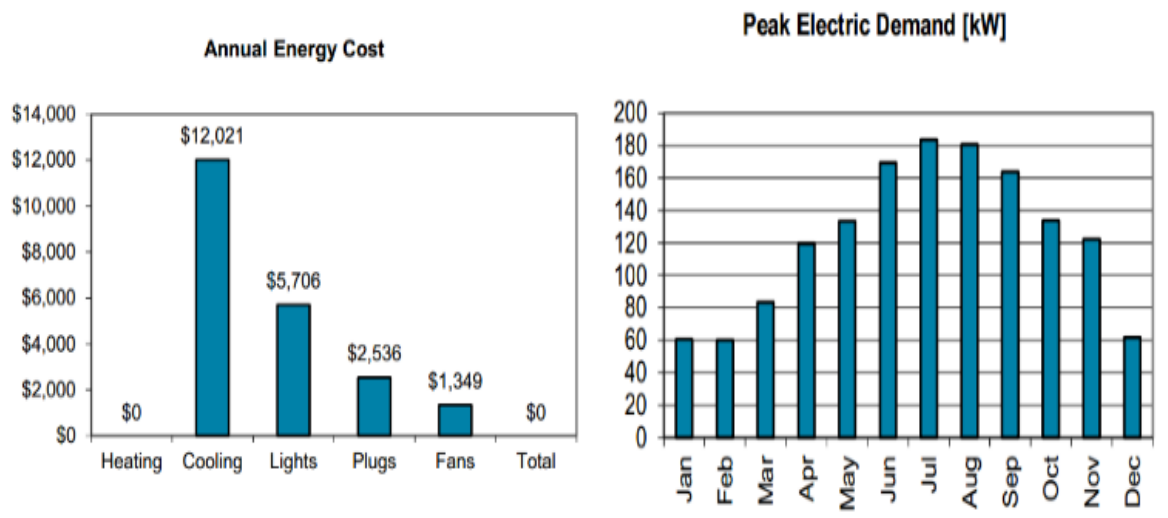

Fig. 10: Annual Energy Cost and Peak Electric Demand (KW)

9. Then several scenarios has been tested and the paper will recommend the best solution as follows. 


\section{RECOMMENDATIONS}

To achieve an optimal energy model for the selected case study The NTC Tower in The Sudan, the paper applied the Generated and Test Technique, where we make our ideas under test to perform them using the Autodesk Ecotect Analysis software. Several ideas were generated and tested using Ecotect to evaluate its effect on the model energy performance, as follows:

1. Solar Panel efficient:
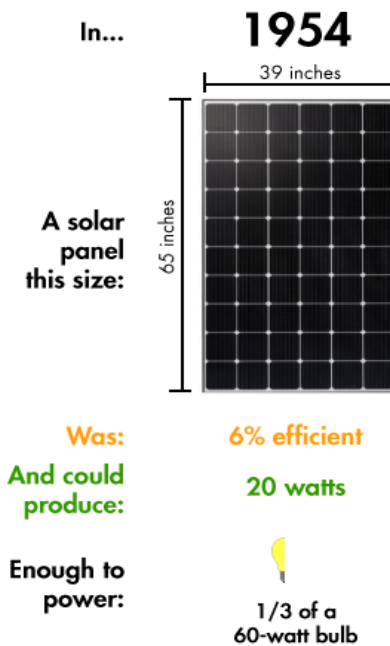

2012

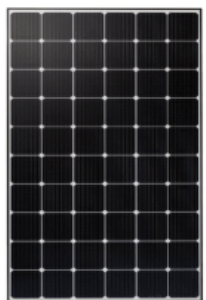

$15 \%$ efficient

200 watts

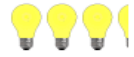

3 and $1 / 3$
2015

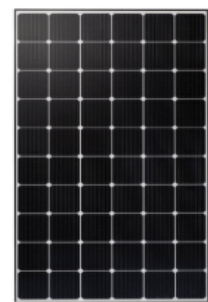

$20 \%$ efficient

265 watts

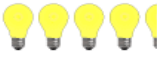

4 and $2 / 5$

60-watt bulbs

Fig. 11: Using multi-crystalline solar cells, which is $11 \%$ more efficient than the used ones will increase the electricity generated from the current PVC systems by $11 \%$.

2. Building envelop must be carefully designed to avoid thermal gain or thermal bridges.
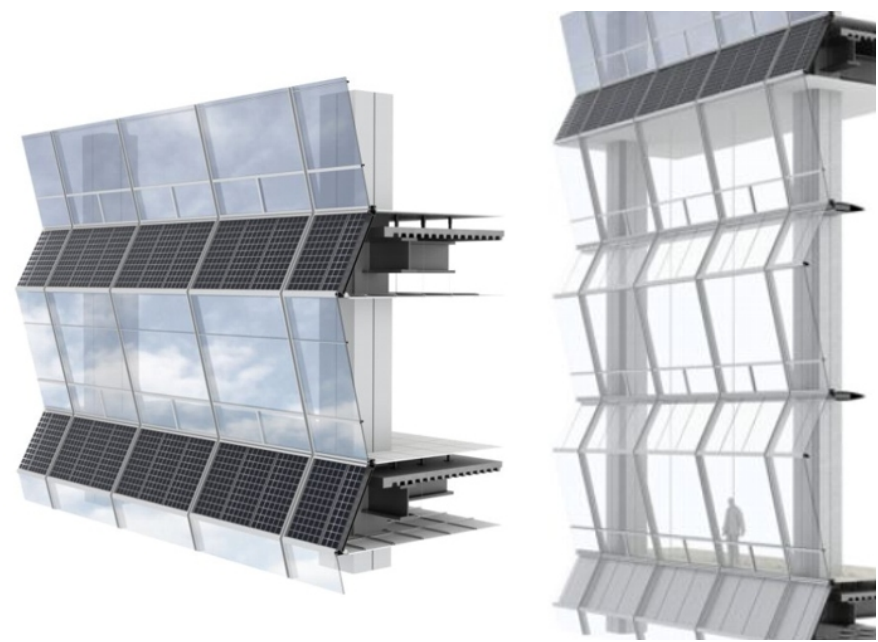

Fig. 12: Rotating the solar cells used in the south western side of the tower $10^{\circ}$, will increase the electricity generated from the current PVC systems by $5 \%$.

3. Using the same suggested envelop in the eastern side will increase the electricity generated from the PVC systems by $15 \%$.

a. Roof integration, using more solar cells from the type multicrystalline solar cells will increase $9 \%$ of the electricity generated by the solar system. In an area equal to 550 square, meter available in the Roof. 

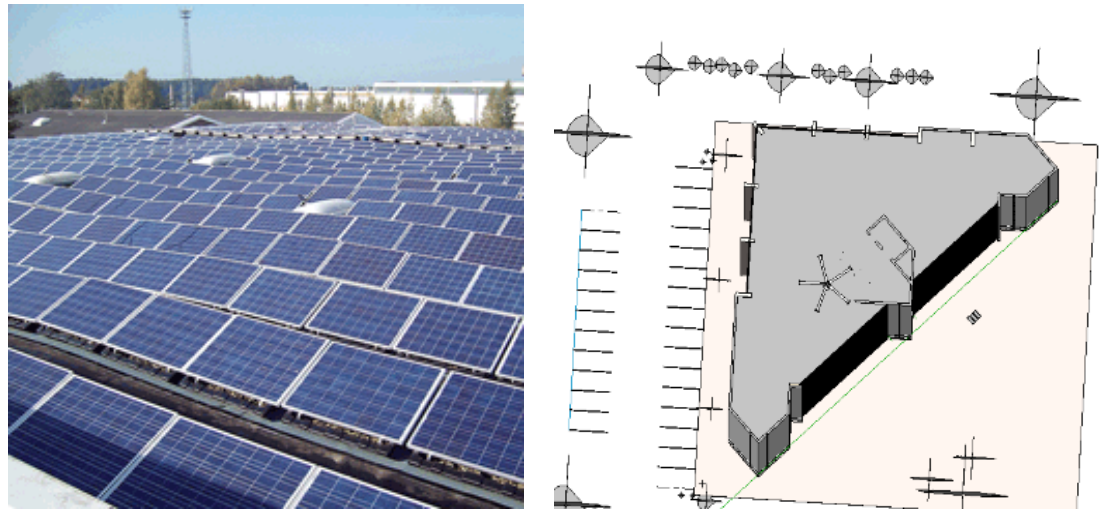

Fig. 13: Integrating Solar cells in the Roof of the tower.

4. Solar energy and building integration technology also requires the integration of construction process and technology, in addition to the conventional construction, there also need to conduct the complex construction of waterway and circuit and to complete the installation and debugging tasks of solar equipment's .

5. Economic Analysisand cost benefit is required to compare the advantages and the cost of using PVC system integrated in the building construction.

6. Off-grid or Grid connected. Even if an architect creates a zero energy building by producing the amount of electricity needed for the tower with on-site solar energy generation, it is still not recommended to design an off-grid building for; the output of the PV systems is unstable because it varies depending on the weather. Connecting with the grid makes it possible to constantly, supply power to consumers.

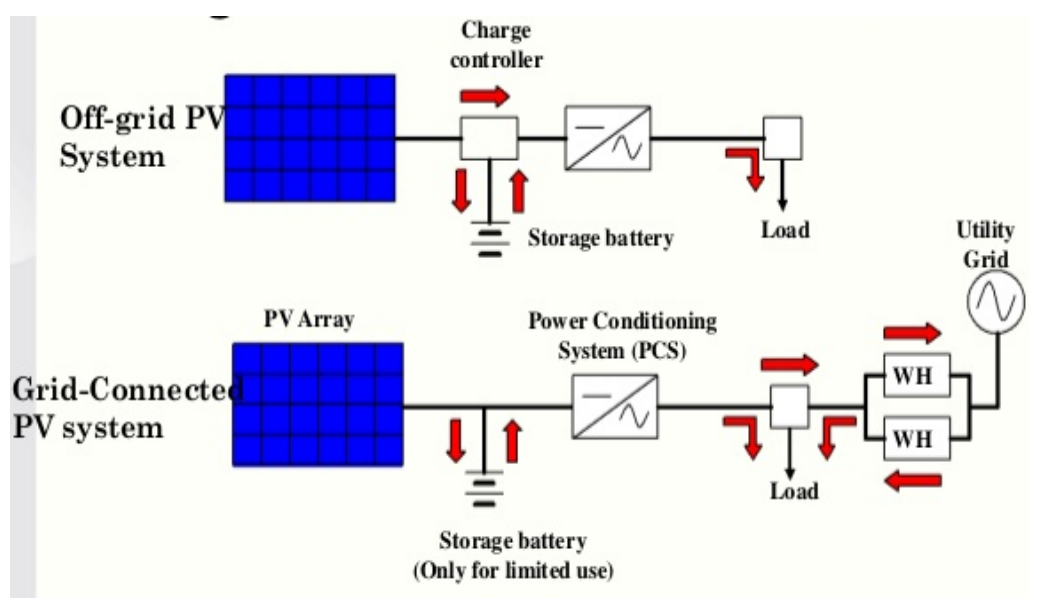

Fig. 14: Off-Grid and Grid-connected

7. Installed systems other than HVAC systems can influence a building's energy performance in two different ways: through their own energy demand and through their production of waste heat which can result in increased cooling loads. Lighting considered the highest in consuming electricity among all other installed systems or other equipment's, the second after HVAC. Using natural lighting is recommended and lighting sensors to maintain the lighting level in spaces within an acceptable level.

8. HVAC systems used in the building for cooling in hot climate or heating in cold weather is consuming the largest part of energy used in the buildings. See Figure 10.

9. HVAC should use energy efficient machines and it should be maintained periodically. In addition, the designer should use passive cooling strategies to minimize the need of mechanical cooling or heating. In addition to the use of smart sensor and thermostat to obtain the thermal comfort needed inside the spaces.

10. Comparative studies show that large differences can exist when using different simulations programs, even for a very simple passive solar building.

\section{CONCLUSIONS}

Solar energy and office building integration technology has broad application prospects, using simulation program will play a significant role in applying the use of solar energy in an efficient way, in the case shown for NTC tower, the researchers were able to increase the percentage of energy consumption covered by the solar energy by $40 \%$, as shown in Figure. 14. 


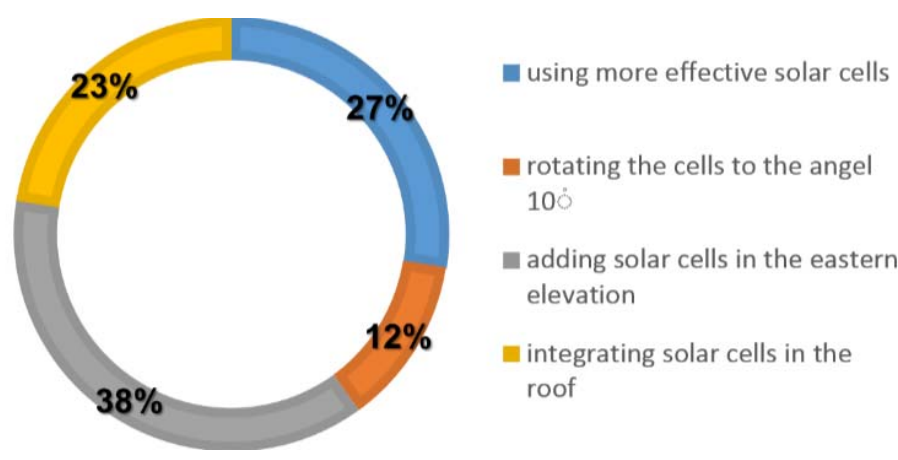

Fig. 15: the increased percentage of solar energy production.

Finding an accurate and efficient way to model and simulate the building to evaluate the energy consumption is of upmost importance.Many future areas can be taken with this model. Use of real data should be used to refine the assumptions made and parameter calculations performed.

\section{REFERENCES}

[1] Marie-Claude Dubois \& Maria Wall, “Architects’ design process in solar-integrated architecture in Sweden, Pages 141-151, published online: 14 May 2012.

[2] Ding Ma, Yi-bing Xue, "Solar Energy and Residential Building Integration Technology and Application", International Journal of Clean Coal and Energy, doi:10.4236/ijcce.2013.22B002 Published Online May 2013 (http://www.scirp.org/journal/ijcce), 2013.

[3] P.J. Bacon,.D.K. Lindley, "The energy crisis in the Sudan: Alternative supplies of biomass", Pg.3.

[4] Y. H. Wang, "Design of solar Residential Building Integration,” Journal of Building Energy Efficiency, Vol. 38, No. 1, 2010, pp.5355.

[5] C. H. Xu and M. L. Qin, "The Application of Solar Energy and Building Integrated Multi-technology," Journal of Construction Science and Technology, No. 5, 2012, pp.69-71.

[6] L. R. Zhang, "The Application of Motor Control Unit in the Cement,” Journal of Equipment Manufacturing Technology, No. 8, 2011, pp. 208-209.

[7] W. Jin, "Application of Building Integrated Photovoltaic (BIPV) in Green Buildings,” Journal of Architecture Technology, Vol. 42, No. 10, 2011, pp. 907-908.

[8] A. Y. Wang and G. Shi, “New Process of Daylighting Technology,”Journal of Architecture, No. 3, 2003, pp. 64-66.

\section{AUTHOR PROFILE}

Omer A. Abuelzein Associate Professor, Ph. D. (Thermal Design of Buildings in Hot -Dry Climate) U. of Newcastle, UK., M. Phil (Housing in Developing Countries) Uwist, UK., Bs. C. (Architectural Engineering) U of K Sudan.

Rania A. Osman Assistant Professor, Ph. D. (Apply the Concept of Green Architecture to Reduce Energy Consumption in Office Buildings) OI University, M. Sc. Physical Planning U of K, Sudan, BSc Architecture, OI University. 